\title{
The Role of Non-Academic Service Quality in an Academic-Oriented Context: Structural Equation Modeling amongst Parents of Secondary Education Students
}

\author{
Thao-Thanh Thi Phan \\ Thanh Do University, Kim Chung, Hoai Duc, Hanoi, Vietnam \\ https://orcid.org/0000-0002-9511-9527 \\ Ha-Giang Thi Tran \\ Hanoi Metropolitan University, Cau Giay, Hanoi, Vietnam \\ http://orcid.org/0000-0002-6061-5424 \\ Le-Huong Thi Nguyen \\ Hoa Binh College of Education, Dan Chu, Hoa Binh, Vietnam \\ https://orcid.org/0000-0002-8103-2797 \\ Tam-Phuong Pham \\ Can Tho University, Ninh Kieu, Can Tho, Vietnam \\ https:// orcid.org/0000-0002-1745-9067 \\ Thang-The Nguyen
}

Vietnam Institute of Educational Sciences, Hoan Kiem, Hanoi, Vietnam http://orcid.org/0000-0002-3998-0099

\section{Hiep-Hung Pham}

Phu Xuan University, Phu Hoi, Hue, Vietnam

EdLab Asia Educational Research and Development Centre, Hanoi, Vietnam https://orcid.org/0000-0003-3300-7770

\section{Thai-Quoc Cao*}

EdLab Asia Educational Research and Development Centre, Hanoi, Vietnam Hanoi University of Social Sciences and Humanities, Hanoi, Vietnam http://orcid.org/0000-0001-8762-4809

\begin{abstract}
In the education sector, the academic factor is considered the primary focus when assessing the service quality of schools. However, the
\end{abstract}

* Corresponding author: Thai-Quoc Cao; Email: thaicao@edlabasia.org 
traditional approach to service quality proposes that the supplemental indicators of quality are just as important in meeting customer expectations. As parents of secondary school students are not directly involved in the academic service of the school, non-academic factors (e.g., administrative quality [ADQ] and physical environment quality [PEQ]) can be considered alternative service quality indicators, subsequently affecting their satisfaction and loyalty. Using data obtained from a survey questionnaire with 230 parents of secondary education students in Vietnam, this study examined non-academic service factors as antecedents of parent satisfaction and loyalty. Results of the exploratory factor analysis (EFA) yielded two factors under the non-academic service dimension: PEQ and ADQ. Results of the structural equation modeling (SEM) showed that while PEQ affects loyalty both directly and indirectly, ADQ affects loyalty only indirectly through satisfaction. Implications for stakeholders, including school principals and policymakers, have been drawn from the findings of this study.

Keywords: administrative quality; non-academic service quality; parent loyalty; parent satisfaction; physical environment quality; secondary education

\section{Introduction}

With a growing population and an ever-fiercer competition in the market, Vietnam's educational sector is striving to adapt to a fast-changing world and the rapid development of the country. Amidst this situation, the secondary education sector in Vietnam has to deal with two major obstacles. The first obstacle is unique to the public secondary school, which emerged from the inevitable transition toward fiscal autonomy of public education in Vietnam. Traditionally, with governmental support, the tuition fee for general secondary education is substantially lower than that of their private counterpart. However, with the transition toward fiscal autonomy, the public education sector has to persuade parents to become more accepting toward an increased tuition fee while improving the quality of education to retain students (Nguyen, 2019). The second obstacle is an alias of Vietnam's booming economy and population. The substantial profitability of the quasi-market of educational service in Vietnam has led to ever more competition (Lan Anh, 2015). This tendency has pushed the typically conservative public school into the context of the already competitive educational market amongst private secondary schools. While various stakeholders are contending the education market, emphasizing the importance of applying marketing perspectives in the secondary education sector has dramatically increased, since a slight advantage can decide the survivability of a school (Kassim et al., 2010; Sharif \& Kassim, 2012).

From the traditional marketing approach, customer satisfaction and loyalty are critical factors related to the success of an organization (Kaura et al., 2015). This is especially true in secondary education, where the decision regarding in which school to enroll their children is a financial one made by parents. When compared with lower education levels, the decision to choose the secondary school is valued more greatly since this is the stepping stone for the children's tertiary education or future career (Rolfsman, 2020; Savolainen et al., 2008). The school with higher 
parent satisfaction and loyalty performs more effectively in the educational market (Li \& Hung, 2009). Therefore, gaining the satisfaction and loyalty of parents, who are also the purchasers of the service, is decisive to gaining the competitive edge over competitors.

In traditional business, improving service quality is one way to increase customer satisfaction and loyalty (Lee, 2017), a fact that also applies to educational service (Hemsley-Brown et al., 2010; Pham \& Lai, 2016). However, there are also inherent differences between the education and other business sectors. While customer perception about service quality in other businesses depends on both the tangible (physical manifestation of the company) and intangible (the service provided by the employees), the assessor of education quality mainly focuses on an ethereal quality, which is the academic side of educational assistance. Indeed, previous research on student perceptions of educational quality has pointed out that academic factors have a more substantial role in the overall student assessment compared with non-academic ones (Teeroovengadum et al., 2019). However, considering parents as the purchasers of educational services, the oversight of non-academic service quality can make the evaluation of service quality imprecise.

The reasons for the potential overlook lie in the similarities and differences in the service experience of parents and students in education. Like with the students, parent satisfaction and loyalty are mainly based on the academic quality of the school. However, unlike students, who directly experience the secondary school education, parents' perception about the academic quality is based on a more indirect assessment, that of school image (Li \& Hung, 2009), or their children's academic results and personal transformation (Harvey \& Green, 1993; Teeroovengadum et al., 2016). Meanwhile, most parents have to deal directly with non-academic issues related to their children's education, such as administrative issues and financial matters. Therefore, from a marketing perspective, examining the parents' perceptions of non-academic service quality in secondary school might provide valuable information both in terms of theory and practice regarding parents' assessment of service quality, and helpful advice for educational institutions to increase their market competitiveness.

As there is currently no research on the effect of non-academic service quality on the level of satisfaction and loyalty with secondary education students, this research, to the best of our knowledge, may be the first to strive to address this research issue. Therefore, the main goal of this study is to examine to what extent non-academic service factors affect parent satisfaction and loyalty. Particularly, two research questions have arisen from this research goal:

1. What components constitute the non-academic service factors in the context of secondary education in Vietnam?

2. How do non-academic service factors affect parent satisfaction and loyalty in the context of secondary education in Vietnam?

To address the research questions, exploratory factor analysis (EFA) was conducted to examine and adapt an established questionnaire to measure parents' 
assessment of non-academic service quality. Subsequently, confirmatory factor analysis (CFA) and structural equation modeling (SEM) were performed to examine the model fit and the role of non-academic service quality on parent satisfaction and loyalty.

The findings of this study have both academic and practical implications. In terms of academic implications, this study, to the best of our knowledge, is the first ever effort to investigate non-academic service factors as determinants of parent satisfaction and loyalty in a secondary education context. In terms of practical implications, school principals and policymakers are amongst the key stakeholders who may benefit from this study.

\section{Literature Review}

\section{Parent Satisfaction and Loyalty}

Satisfaction and loyalty are two prominent factors examined in marketing research, and are direct antecedents of customer retention and business success (Hallowell, 1996; Kandampully \& Suhartanto, 2000; Kasiri et al., 2017). Furthermore, satisfaction and loyalty are closely related concepts and should be included conjointly to explain best success of service providers, including educational institutions. Satisfaction is identified as one of the most viable direct determinants of loyalty. This assertion has been verified in many different contexts, such as tourism (Eid, 2015), retail (Kamran-Disfani et al., 2017), banking (Bloemer et al., 1998), and e-commerce (Eid, 2011).

In the educational context, we follow the definition of Fantuzzo et al. (2006), which operationalizes parent satisfaction according to the degree of expectation being met. Satisfaction can also serve as the primary pathway to customer loyalty, which is also an essential factor in the marketing field. Customer loyalty in the educational context can be defined according to the long-term commitment to the favored educational institution of parents (Li \& Hung, 2009). As the concept of loyalty can be specified by different theoretical approaches (e.g., behavioral loyalty, intentional loyalty), in this study, we followed Li and Hung (2009) in using the hybrid system to measure loyalty, which has been commonly applied in educational contexts.

\section{Non-Academic Service Quality}

The taxonomy of the educational service quality concept has been defined in various ways in literature. As summarized by Sharif and Kassim (2012), service quality can be defined either by the excellence of service delivery or the success in meeting customer expectations. In the educational context, the latter approach is often the preferred avenue to examine service quality. As previous research has mainly relied on student assessment, the expectation of service quality is primarily defined by the added value from academic indicators, while neglecting the non-academic aspect of the service (Sharif \& Kassim, 2012). Teeroovengadum et al.'s (2016) scale measuring both non-academic and academic service quality has shown that the factors related to non-academic service quality have a lesser effect on students' assessment of service quality. However, from the parents' 
perspective, the aspect of service quality that they often directly have exposure to is primarily non-academic factors.

Previous research on the assessment of patients' relatives on medical service quality has shown that interpersonal relationships with the medical staff and the physical environment are important indicators of service quality since the relatives do not have direct exposure to the medical care and enough technical knowledge about the service (Mohammad Mosadeghrad, 2013). Therefore, to parents, the non-academic factors may also play an essential role in assessing service quality. According to Sharif and Kassim (2012), non-academic service quality is crucial in choosing educational institutions when the other academic criteria are identical. To better distinguish the sub-concepts of academic and non-academic service quality, we conceptualize non-academic service quality, based on Sharif and Kassim (2012), as the factors related to the infrastructure and management activities of the educational institution. Therefore, this study aimed to explore the effects of non-academic service quality on parent satisfaction and loyalty. EFA was used to unveil the factors of non-academic service quality. Previous studies, using students as studied objects, have revealed a positive association between non-academic service quality and satisfaction and loyalty (see Kardoyo et al., 2019; Mulyono et al., 2020; Sultan \& Yin Wong, 2013). Subsequently, these factors were used to answer our main research hypotheses, which expect non-academic service quality elements to significantly increase parent satisfaction and loyalty.

\section{Conceptual Model}

Based on the above review of literature, we built our conceptual model as illustrated in Figure 1. Specifically, it is suggested that satisfaction and non-academic service factors both have a positive effect on loyalty. Meanwhile, non-academic service factors are also proposed to have a direct effect on satisfaction. In other words, satisfaction is supposed to have a partial mediating effect on the link between non-academic service factors and loyalty.

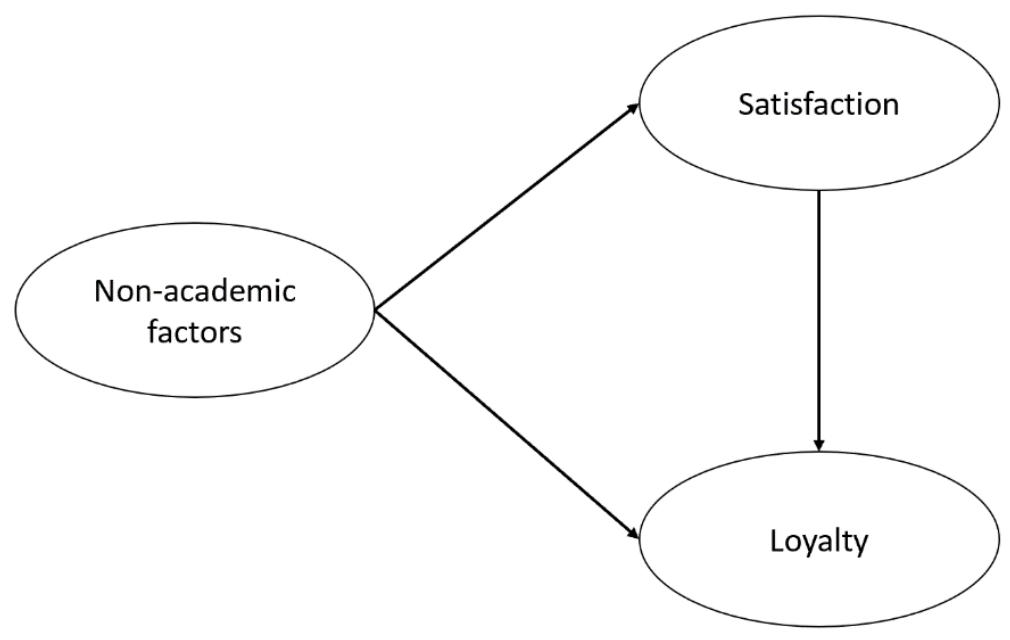

Figure 1: Conceptual model of the research 


\section{Methodology}

Data Collection

To answer the research questions, an online survey questionnaire was distributed to Vietnamese parents of secondary school students. We used the snowball data collection method to secure respondents. Specifically, we utilized our network of educators and teachers in secondary schools across Vietnam to forward the survey to the parents. Every two weeks during the data collection process, a follow-up email was sent to remind the unresponsive parents to complete the survey. The final sample comprised 230 respondents deemed suitable for SEM (Hoogland \& Boomsma, 1998). Table 1 shows an overview of the demographic profile of the sample.

Table 1: The demographic background of the respondents

\begin{tabular}{|l|l|}
\hline Characteristic & Frequency (n \& \%) \\
\hline Gender & \\
\hline Male & $36(15.7)$ \\
\hline Female & $188(81.7)$ \\
\hline Prefer not to say & $6(2.6)$ \\
\hline Age & \\
\hline 35 years old and under & $18(7.8)$ \\
\hline $36-40$ years old & $70(30.4)$ \\
\hline $41-45$ years old & $83(36.1)$ \\
\hline $46-50$ years old & $41(17.8)$ \\
\hline 50 years old and over & $18(7.8)$ \\
\hline Type of work & \\
\hline Public sector & $131(57.0)$ \\
\hline Private sector & $71(30.9)$ \\
\hline Other & $28(12.2)$ \\
\hline Residency & \\
\hline Hanoi or Ho Chi Minh City & $177(77.0)$ \\
\hline Other & $53(23.0)$ \\
\hline Level of education & $95(41.3)$ \\
\hline Lower than undergraduate & \\
\hline Undergraduate education & \\
\hline & \\
\hline
\end{tabular}




\begin{tabular}{|l|l|}
\hline Characteristic & Frequency (n \& \%) \\
\hline Postgraduate education & $109(47.4)$ \\
\hline Other & $4(1.7)$ \\
\hline The grade of the children & \\
\hline Lower secondary education & $147(63.8)$ \\
\hline Upper secondary education & $83(36.1)$ \\
\hline Total & 230 \\
\hline
\end{tabular}

\section{Instrument Development}

A positivism paradigm was employed to help answer the research questions. The research questionnaire was developed based on the Higher Education Service Quality (HESQUAL) scale (Teeroovengadum et al., 2016). The measurement has a total of five main factors and eleven sub-factors. From the conceptualization mentioned above of non-academic service quality, we chose five sub-factors of the HESQUAL scale to measure non-academic service factors, as follows: (i) administrative processes (ADP); (ii) attitude and behavior of staff (ATB); (iii) support facilities quality (SFQ); (iv) learning setting (LNS); and (v) support infrastructure (SPI).

To use the questionnaire on Vietnamese parents, a translated version of the survey was required. Following the recommendations of Epstein et al. (2015), we employed back-translation to translate the English questionnaire into Vietnamese. The original English version (E1) was translated into Vietnamese (V1) by a coauthor of this paper. After this, another co-author who had never seen the E1 version was asked to back-translate V1 into English (E2). The three versions of the questionnaire (i.e., E1, V1, \& E2) were compared and revised by all authors of the paper, subsequently leading to the second Vietnamese version (V2). An educational practitioner and a researcher were invited to examine the V2 and E1 versions for face validity. Some revisions on the terminology in the questionnaire were made based on the comments of the two invited experts.

\section{Results}

\section{Exploratory Factor Analysis}

As the questionnaire had been translated into Vietnamese, we decided to conduct EFA to examine the latent constructs of non-academic service quality. Following the procedure of Hair et al. (1998), the items with factor loadings larger than 0.50 were considered significant and kept. Meanwhile, items with factor loadings smaller than 0.4 were excluded. Table 2 shows the factor structure of the 13 observed variables examined by the EFA. As shown in Table 2, rather than having five initial factors, this analysis revealed two main factors, labeled physical environment quality (PEQ) and administrative quality (ADQ). 
Table 2: The exploratory factor analysis results

\begin{tabular}{|c|c|c|c|}
\hline $\begin{array}{l}\text { Factor } \\
\text { (Latent } \\
\text { variable) }\end{array}$ & Component & $\begin{array}{l}\text { Factor } \\
\text { loading }\end{array}$ & $\begin{array}{l}\text { Cronbach } \\
\text { alpha }\end{array}$ \\
\hline \multirow{9}{*}{ PEQ } & $\begin{array}{l}\text { SPI1: Availability of adequate cafeteria } \\
\text { infrastructure }\end{array}$ & 0.840 & \multirow{9}{*}{0.929} \\
\hline & $\begin{array}{l}\text { SPI2: Availability of adequate sports } \\
\text { infrastructure }\end{array}$ & 0.851 & \\
\hline & $\begin{array}{l}\text { SPI3: Availability of adequate recreational } \\
\text { infrastructure }\end{array}$ & 0.778 & \\
\hline & $\begin{array}{l}\text { SPI4: Availability of adequate library } \\
\text { infrastructure }\end{array}$ & 0.751 & \\
\hline & $\begin{array}{l}\text { SFQ2: Amount of opportunity for sports } \\
\text { and recreational facilities }\end{array}$ & 0.825 & \\
\hline & SFQ3: Availability of adequate IT facilities & 0.791 & \\
\hline & LNS1: Having adequate lecture rooms & 0.766 & \\
\hline & $\begin{array}{l}\text { LNS2: Having quiet places to study within } \\
\text { the campus }\end{array}$ & 0.530 & \\
\hline & $\begin{array}{l}\text { LNS3: Availability of adequate teaching } \\
\text { tools and equipment (e.g., projector, } \\
\text { whiteboard) }\end{array}$ & 0.546 & \\
\hline \multirow{4}{*}{ ADQ } & $\begin{array}{l}\text { ADP1: Well-standardized administrative } \\
\text { processes so that there is not much } \\
\text { bureaucracy and useless difficulties }\end{array}$ & 0.853 & \multirow{4}{*}{0.931} \\
\hline & $\begin{array}{l}\text { ADP2: Administrative procedures are } \\
\text { clear and well structured so that service } \\
\text { delivery times are minimum }\end{array}$ & 0.878 & \\
\hline & $\begin{array}{l}\text { ATB1: Willingness of administrative staff } \\
\text { members to help students }\end{array}$ & 0.923 & \\
\hline & $\begin{array}{l}\text { ATB2: Ability of administrative staff } \\
\text { members to solve students' problems }\end{array}$ & 0.848 & \\
\hline
\end{tabular}

Nine items loaded onto PEQ, with factor loadings ranging from 0.53 to 0.85 . The second factor, $\mathrm{ADQ}$, had factor loadings ranging from 0.85 to 0.92 . All items used for the analysis are presented in Table 2. The EFA results therefore provide the answer for research question 1 (What components constitute the non-academic service factors in the context of secondary education in Vietnam?). There are two specific factors pertaining to the non-academic service dimension of secondary education in Vietnam, namely PEQ and ADQ.

Figure 2 represents our adjusted conceptual model based on the EFA results. 


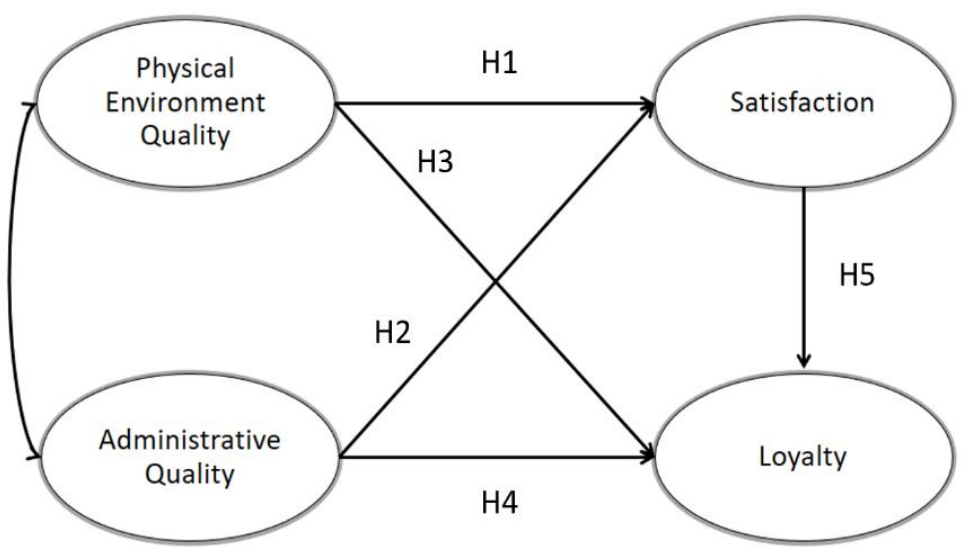

Figure 2: The adjusted conceptual model of the research after exploratory factor analysis

Particularly, we propose that satisfaction has a positive effect on loyalty. At the same time, we suggest that satisfaction partially mediates the relationships of PEQ-loyalty and ADQ-loyalty. Under these circumstances, five hypotheses are proposed:

H1: PEQ has a significant positive effect on satisfaction.

H2: ADQ has a substantial significant positive effect on satisfaction.

H3: PEQ has a significant positive effect on loyalty.

H4: ADQ has a significant positive effect on loyalty.

H5: Satisfaction has a significant positive effect on loyalty.

\section{Confirmatory Factor Analysis}

To assess how well the measurement model fits with the observed data, CFA was conducted. Specifically, all the goodness of fit (GOF) indices were satisfied with their acceptable level, indicating that the model fit with the observed data. Table 3 presents the GOF indices of the model and their respective cut-off levels for a good fit.

Table 3: Results of multiple fit indices

\begin{tabular}{|l|l|l|}
\hline Index & Result & Acceptable level \\
\hline Chi-square & 254.159 & - \\
\hline Degree of freedom & 174 & - \\
\hline $\begin{array}{l}\text { Chi-square/Degree of } \\
\text { freedom }\end{array}$ & 1.461 & $<5$ \\
\hline GFI & 0.908 & $>0.9$ \\
\hline AGFI & 0.878 & $>0.8$ \\
\hline NFI & 0.949 & $>0.9$ \\
\hline RMSEA & 0.045 & $<0.08$ \\
\hline CFI & 0.983 & $>0.9$ \\
\hline
\end{tabular}


Regarding the issues of convergent validity and discriminant validity, the factor loadings, composite reliability (CR) scores, and average variance extracted (AVE) scores of the model were examined (Tables 4 and 5).

Table 4: Results of factor loading for Confirmatory Factor Analysis

\begin{tabular}{|c|c|c|}
\hline $\begin{array}{c}\text { Factor } \\
\text { (Latent } \\
\text { variable) }\end{array}$ & Item & Factor loading \\
\hline \multirow{9}{*}{ PEQ } & $\begin{array}{l}\text { SFQ2: Amount of opportunity for sports and recreational } \\
\text { facilities }\end{array}$ & 0.824 \\
\hline & SFQ3: Availability of adequate IT facilities & 0.803 \\
\hline & $\begin{array}{l}\text { LNS3: Availability of adequate teaching tools and } \\
\text { equipment (e.g., projector, whiteboard) }\end{array}$ & 0.691 \\
\hline & LNS2: Having quiet places to study within the campus & 0.649 \\
\hline & LNS1: Having adequate lecture rooms & 0.760 \\
\hline & SPI4: Availability of adequate library infrastructure & 0.767 \\
\hline & SPI3: Availability of adequate recreational infrastructure & 0.797 \\
\hline & SPI2: Availability of adequate sports infrastructure & 0.801 \\
\hline & SPI1: Availability of adequate cafeteria infrastructure & 0.768 \\
\hline \multirow{4}{*}{ ADQ } & $\begin{array}{l}\text { ADP2: Administrative procedures are clear and well } \\
\text { structured so that service delivery times are minimum }\end{array}$ & 0.958 \\
\hline & $\begin{array}{l}\text { ADP1: Well-standardized administrative processes so that } \\
\text { there is not much bureaucracy and useless difficulties }\end{array}$ & 0.926 \\
\hline & $\begin{array}{l}\text { ATB2: Ability of administrative staff members to solve } \\
\text { students' problems }\end{array}$ & 0.768 \\
\hline & $\begin{array}{l}\text { ATB1: Willingness of administrative staff members to help } \\
\text { students }\end{array}$ & 0.786 \\
\hline \multirow{3}{*}{ SAT } & SAT3. This school has met my expectations & 0.941 \\
\hline & SAT2. My choice of this school was a wise one & 0.964 \\
\hline & SAT1. I am satisfied with the decision to choose this school & 0.939 \\
\hline LOY & $\begin{array}{l}\text { LOY5. When talking about school with my relatives or } \\
\text { friends, I will praise this school voluntarily. }\end{array}$ & 0.898 \\
\hline
\end{tabular}




\begin{tabular}{|l|l|l|}
\hline $\begin{array}{c}\text { Factor } \\
\text { (Latent } \\
\text { variable) }\end{array}$ & Item & Factor loading \\
\hline \multirow{2}{*}{} & $\begin{array}{l}\text { LOY4. I will encourage my relatives or friends to let their } \\
\text { children study in this school }\end{array}$ & 0.923 \\
\cline { 2 - 3 } & $\begin{array}{l}\text { LOY3. When my relatives or friends need information } \\
\text { about secondary school, I will voluntarily recommend this } \\
\text { school }\end{array}$ & 0.916 \\
\cline { 2 - 3 } & $\begin{array}{l}\text { LOY2. When my child is entering secondary school, this } \\
\text { school will be my first choice }\end{array}$ & 0.824 \\
\cline { 2 - 3 } & $\begin{array}{l}\text { LOY1. If I have a child studying in secondary school, I will } \\
\text { continue to let him/her attend the same school. }\end{array}$ & 0.819 \\
\hline
\end{tabular}

Table 5: Convergent and discriminant validity

\begin{tabular}{|l|l|l|l|l|l|l|}
\hline \multirow{2}{*}{ Construct } & \multirow{2}{*}{ CR } & \multirow{2}{*}{ AVE } & \multicolumn{4}{|c|}{ Factor correlation } \\
\cline { 4 - 7 } & & & SAT & PEQ & ADQ & LOY \\
\hline PEQ & 0.926 & 0.584 & 0.764 & & & \\
\hline ADQ & 0.921 & 0.746 & 0.622 & 0.864 & & \\
\hline SAT & 0.964 & 0.899 & 0.519 & 0.646 & 0.948 & \\
\hline LOY & 0.943 & 0.769 & 0.587 & 0.535 & 0.770 & 0.877 \\
\hline
\end{tabular}

Note: PEQ - physical environment quality; $A D Q$ - administrative quality; SAT - satisfaction; LOY - loyalty; CR - composite reliability; AVE - average variance extracted

Regarding the factor loadings of the observed variables, the PEQ factor loadings ranged from 0.649 to 0.824 , ADQ from 0.768 to 0.958 , satisfaction from 0.939 to 0.964 , and loyalty from 0.819 to 0.923 . Overall, the factor loadings of the observed variables were relatively high. Regarding the convergent validity issue, as shown in Table 4, the CR and AVE scores of the concepts were higher than their thresholds, 0.7 and 0.5 , respectively. The discriminant validity of the questionnaire was examined by comparing the AVE scores and the squared correlation coefficients between factors. The AVE scores were higher than the squared correlation coefficients, which indicates that the criteria for discriminant validity were satisfied.

\section{Path Analyses and Hypotheses Testing}

Table 6 shows the standardized regression estimates and the $p$-values of the exogenous variables. 
Table 6: Results of the structural equation modelling

\begin{tabular}{|c|c|c|c|}
\hline & $\begin{array}{c}\text { Standardized } \beta \\
\text { coefficient }\end{array}$ & $p$-value & Hypothesis \\
\hline \multicolumn{4}{|c|}{ Dependent variable: $S A T$} \\
\hline PEQ & 0.197 & 0.007 & $\mathrm{H} 1$ is supported \\
\hline ADQ & 0.524 & $* * *$ & $\mathrm{H} 2$ is supported \\
\hline $\mathrm{R}^{2}$ & $44.1 \%$ & & \\
\hline \multicolumn{4}{|c|}{ Dependent variable: LOY } \\
\hline SAT & 0.674 & $* * *$ & $\mathrm{H} 5$ is supported \\
\hline PEQ & 0.283 & $* * *$ & $\mathrm{H} 3$ is supported \\
\hline ADQ & -0.077 & 0.261 & $\mathrm{H} 4$ is not supported \\
\hline $\mathrm{R}^{2}$ & $64.5 \%$ & & \\
\hline
\end{tabular}

Regarding the effect of non-academic service constructs on satisfaction, the regression paths of the SEM showed that PEQ $(\beta=0.20, p=0.007)$ and ADQ $(\beta=0.52, p<0.001)$ have a significant positive effect on satisfaction, indicating that higher non-academic service constructs come with higher parent satisfaction. Therefore, hypotheses $\mathrm{H} 1$ and $\mathrm{H} 2$ are supported. Higher PEQ is also directly associated with higher loyalty $(\beta=0.28, p<0.001)$, indicating that increasing the PEQ heightens parents' commitment. This relationship supports hypothesis H3. However, ADQ does not significantly affect loyalty $(p=0.261)$, and therefore hypothesis H4 is rejected. Lastly, satisfaction showed the strongest effect on loyalty $(\beta=0.67, p<0.001)$, which provides support for hypothesis $\mathrm{H} 5$.

These above findings provide an answer to the second research question of this study (How do non-academic service factors affect parent satisfaction and loyalty in the context of secondary education in Vietnam?). Specifically, both PEQ and ADQ directly affect satisfaction, while only PEQ directly affects loyalty. In the same vein, satisfaction directly affects loyalty. In other words, satisfaction partially mediates the relationship between PEQ and loyalty and fully mediates the relationship between ADQ and loyalty. Overall, the non-academic service quality explained $44.1 \%$ of the variance in satisfaction. The effect of satisfaction, PEQ, and ADQ on loyalty explained $64.5 \%$ of the variance in loyalty.

\section{Total Effect of Direct and Indirect Antecedents of Parent Loyalty}

Table 7 shows calculations of the total effect of the antecedents on loyalty. Amongst all, satisfaction has only a direct but also the highest effect (total effect $=$ 0.674) on loyalty. This is followed by PEQ, which has both direct and indirect effects (total effect $=0.416$ ), and ADQ, which has only an indirect effect (total effect $=0.353$ ). 
Table 7: Direct, indirect, and total effects of physical environment quality, administrative quality, and satisfaction on loyalty

\begin{tabular}{|l|l|l|c|}
\hline Antecedent & $\begin{array}{l}\text { Direct effect route and } \\
\text { magnitude }\end{array}$ & $\begin{array}{l}\text { Indirect effect route and } \\
\text { magnitude }\end{array}$ & $\begin{array}{l}\text { Total } \\
\text { effect }\end{array}$ \\
\hline PEQ & PEQ - loyalty: 0.28 & $\begin{array}{l}\text { PEQ - satisfaction - loyalty: } \\
0.197 * 0.674=0.133\end{array}$ & 0.416 \\
\hline ADQ & - & $\begin{array}{l}\text { ADQ - satisfaction - loyalty: } \\
0.524 * 0.674=\end{array}$ & 0.353 \\
\hline Satisfaction & Satisfaction - loyalty: 0.674 & - & 0.674 \\
\hline
\end{tabular}

\section{Discussion and Conclusion}

As far as we are aware, no research has been conducted on the effects of parents' assessment of non-academic service quality on their satisfaction and loyalty in secondary education. By surveying 230 Vietnamese parents, this study fills this research gap by pointing out that besides increasing academic quality, secondary education institutions should also focus on improving ADQ and PEQ to increase parent satisfaction and loyalty. The results of this research make several theoretical contributions to the literature on educational service quality.

\section{Academic Implications}

First, this research has re-established that satisfaction is still the main predictor of loyalty (Brandano et al., 2019; Kandampully \& Suhartanto, 2000; Kasiri et al., 2017; Pham et al., 2019). The results also showed that the non-academic dimension is composed of two factors, PEQ and ADQ. These factors have both direct and indirect effects on parent satisfaction and loyalty. Furthermore, the total direct and indirect effects of PEQ more significantly affect parent loyalty than the indirect effect of ADQ. This result aligns with previous research on students' assessment of ADQ and PEQ. According to Grönroos (2011), the evaluation of value can be incrementally added throughout the service experience of the customer by exposure to different indicators of quality. As the exposure to PEQ is unavoidable when parents are present at the educational institution, the value added incrementally may contribute to the positive relationship with satisfaction and loyalty. This can also be used to explain the insignificant relationship between ADQ and loyalty. According to lin and Tsai (2008), students perceived that ADQ does not affect their loyalty due to the little interaction between them and the administrative staff.

Similarly, this research has shown that positive ADQ experiences affect the only the satisfaction of parents. Unlike ADQ, the exposure to PEQ is consistent and can be accounted for by parent recommendation and loyalty to the school. PEQ has been found to affect both parent satisfaction and loyalty through either direct or indirect paths, which is also consistent with previous research on students' assessment (Hemsley-Brown et al., 2010; Wiers-Jenssen et al., 2002). 


\section{Practical Implications}

The findings of this research have two main direct practical implications for secondary education institutions. First, secondary schools should focus on increasing the quality of PEQ and ADQ to increase parent satisfaction and loyalty. As previous research has mainly depended on the academic quality of educational institutions, schools with equal academic quality and a stronger focus on non-academic aspects can have a stronger competitive edge than their counterparts (Kassim et al., 2010). Second, when distributing resources to increase the competitive advantage over non-academic service quality, more focus should be placed on PEQ than ADQ as PEQ has a direct effect on both satisfaction and loyalty, while $\mathrm{ADQ}$ has a direct effect on satisfaction only but not loyalty. Additionally, the total effect on loyalty stemming from PEQ is higher than that from ADQ. Thus, school principals and governmental agencies should focus more on PEQ constitutions such as libraries, cafeterias, recreational infrastructure, sport infrastructure, and so forth.

\section{Limitations and Suggestions for Future Research}

The current research also had several limitations (Vuong, 2020). First, as this research was one of the first attempts to examine the effect of non-academic service quality from parents' perspective, the survey developed to test our hypotheses requires further investigation regarding its validity and reliability in different contexts. We suggest future research to replicate these results by including other measurements of non-academic service quality to predict parent satisfaction and loyalty. Second, as Asian parents in general and Vietnamese parents in specific have certain unique traits represented by cultural factors (Loh $\&$ Teo, 2017), a more representative sample across the globe is required to further confirm how non-academic service quality affects parent satisfaction and loyalty.

Third, the non-significant ADQ results may be the result of overlooking other important determinants of loyalty, such as school image. We recommend that further research use a more detailed model with relevant variables to test this effect. Lastly, although we were able to collect a diverse and large sample, our sampling method relied on educators and teachers to distribute the survey to the parents. This may have triggered the demand effect, where participants try to please the authoritative individual (teacher/researcher) by behaving in a desirable manner (Nichols \& Maner, 2008). Although the consent form of this research assured the anonymity of the respondents, future research should utilize a more randomized sampling method to replicate the results of this research.

\section{Funding and Acknowledgements:}

This work is part of the project "Model of K-12 school governance from the lens of educational service" - number B2019 - VGK-02 (Mô hình quản trị cơ sở giáo dục phổ thông theo tiếp cận quản trị dịch vụ giáo dục, số B2019 -VGK-02).

The authors would like to thank the funder for this valuable support. 


\section{References}

Bloemer, J., De Ruyter, K., \& Peeters, P. (1998). Investigating drivers of bank loyalty: The complex relationship between image, service quality and satisfaction. International Journal of Bank Marketing, 16(7), 276-286. https://doi.org/10.1108/02652329810245984

Brandano, M. G., Osti, L., \& Pulina, M. (2019). How motivations and satisfaction influence wine tourists' loyalty? An analysis of the Italian case. International Journal of Culture, Tourism and Hospitality Research, 13(1), 55-69. https://doi.org/10.1108/IJCTHR-04-2018-0054

Eid, M. (2011). Determinants of e-commerce customer satisfaction, trust, and loyalty in Saudi Arabia. Journal of Electronic Commerce Research, 12(1), 78-93. http://www.jecr.org/sites/default/files/12_1_p05.pdf

Eid, R. (2015). Integrating Muslim customer perceived value, satisfaction, loyalty and retention in the tourism industry: An empirical study. International Journal of Tourism Research, 17(3), 249-260. https://doi.org/10.1002/jtr.1982

Epstein, J., Osborne, R. H., Elsworth, G. R., Beaton, D. E., \& Guillemin, F. (2015). Crosscultural adaptation of the Health Education Impact Questionnaire: Experimental study showed expert committee, not back-translation, added value. Journal of Clinical Epidemiology, 68(4), 360-369. https://doi.org/10.1016/j.jclinepi.2013.07.013

Fantuzzo, J., Perry, M. A., \& Childs, S. (2006). Parent Satisfaction with Educational Experiences Scale: A multivariate examination of parent satisfaction with early childhood education programs. Early Childhood Research Quarterly, 21(2), 142-152. https://doi.org/10.1016/j.ecresq.2006.04.002

Grönroos, C. (2011). Value co-creation in service logic: A critical analysis. Marketing Theory, 11(3), 279-301. https:// doi.org/10.1177/1470593111408177

Hair, J. F., Black, W. C., Babin, B. J., \& Anderson, R. E. (1998). Multivariate data analysis (Vol. 5). Pearson. https://www.amazon.com/Multivariate-Data-AnalysisJoseph-Hair/dp/0138132631

Hallowell, R. (1996). The relationships of customer satisfaction, customer loyalty, and profitability: An empirical study. International Journal of Service Industry Management, 7(4), 27-42. https://doi.org/10.1108/09564239610129931

Harvey, L., \& Green, D. (1993). Defining quality. Assessment \& Evaluation in Higher Education, 18(1), 9-34. https://doi.org/10.1080/0260293930180102

Hemsley-Brown, J., Lowrie, A., Gruber, T., Fuß, S., Voss, R., \& Gläser-Zikuda, M. (2010) Examining student satisfaction with higher education services: Using a new measurement tool. International Journal of Public Sector Management, 23(2), 105-123. https://doi.org/10.1108/09513551011022474

Hoogland, J. J., \& Boomsma, A. (1998). Robustness studies in covariance structure modeling. Sociological Methods \& Research, 26(3), 329-367. https://doi.org/10.1177/0049124198026003003

Kamran-Disfani, O., Mantrala, M. K., Izquierdo-Yusta, A., \& Martínez-Ruiz, M. P. (2017). The impact of retail store format on the satisfaction-loyalty link: An empirical investigation. Journal of Business Research, 77, 14-22. https://doi.org/10.1016/j.jbusres.2017.04.004

Kandampully, J., \& Suhartanto, D. (2000). Customer loyalty in the hotel industry: The role of customer satisfaction and image. International Journal of Contemporary Hospitality Management, 12(6), 346-351. https:/ / doi.org/10.1108/09596110010342559

Kardoyo, K., Pitaloka, L. K., Rozman, R., \& Hapsoro, B. B. (2019). Analyzing universities service quality to student satisfaction; academic and non-academic analyses. International Journal of Higher Education, 9(1), 126. 
https://doi.org/10.5430/ijhe.v9n1p126

Kasiri, L. A., Guan Cheng, K. T., Sambasivan, M., \& Sidin, S. M. (2017). Integration of standardization and customization: Impact on service quality, customer satisfaction, and loyalty. Journal of Retailing and Consumer Services, 35, 91-97. https://doi.org/10.1016/j.jretconser.2016.11.007

Kassim, N. M., Najdawi, M., Al Azmeh, Z., \& Sadiq, H. (2010). Effects of institutional reform on corporate image and value in a developing country context. Measuring Business Excellence, 14(2), 32-45. https:/ / doi.org/10.1108/13683041011047849

Kaura, V., Durga Prasad, C. S., \& Sharma, S. (2015). Service quality, service convenience, price and fairness, customer loyalty, and the mediating role of customer satisfaction. International Journal of Bank Marketing, 33(4), 404-422. https://doi.org/10.1108/IJBM-04-2014-0048

Lan Anh. (2015). Giáo dục muốn phát triển phải cạnh tranh [Competition is required for the development of education]. Vietnamnet. https://vietnamnet.vn/vn/tuanvietnam/giao-duc-muon-phat-trien-phai-canhtranh-274106.html

Lee, S. Y. (2017). Service quality of sports centers and customer loyalty. Asia Pacific Journal of Marketing and Logistics, 29(4), 870-879. https://doi.org/10.1108/APJML-102016-0191

Li, C. K., \& Hung, C. H. (2009). Marketing tactics and parents' loyalty: The mediating role of school image. Journal of Educational Administration, 47(4), 477-489. https://doi.org/10.1108/09578230910967455

lin, C., \& Tsai, Y. H. (2008). Modeling educational quality and student loyalty: A quantitative approach based on the theory of information cascades. Quality $\mathcal{E}$ Quantity, 42(3), 397-415. https://doi.org/10.1007/s11135-006-9051-5

Loh, C. Y. R., \& Teo, T. C. (2017). Understanding Asian students learning styles, cultural influence and learning strategies. Journal of Education \& Social Policy, 7(1), 194-210. https://www.jespnet.com/journals/Vol_4_No_1_March_2017/23.pdf

Mohammad Mosadeghrad, A. (2013). Healthcare service quality: Towards a broad definition. International Journal of Health Care Quality Assurance, 26(3), 203-219. https://doi.org/10.1108/09526861311311409

Mulyono, H., Hadian, A., Purba, N., \& Pramono, R. (2020). Effect of service quality toward student satisfaction and loyalty in higher education. The Journal of Asian Finance, $\begin{array}{llll}\text { Economics and } & \text { 7(10), 929-938. }\end{array}$ https://doi.org/10.13106/jafeb.2020.vol7.no10.929

Nguyen, P. (2019). Tự chủ trong giáo dục phổ thông là xu thế tất yếu [Autonomy in secondary education is an inevitable trend]. Nhan Dan. https://www.nhandan.com.vn/hangthang/item/41735702-"tu-chu-trong-giaoduc-pho-thong-la-xu-the-tat-yeu".html

Nichols, A. L., \& Maner, J. K. (2008). The good subject effect: Investigating participant demand characteristics. The Journal of General Psychology, 135(2), 151-166. https://doi.org/10.3200/GENP.135.2.151-166

Pham, H.-H., \& Lai, S. L. (2016). Higher education as an extended duration service. Journal of Studies in International Education, 20(5), 454-471. https://doi.org/10.1177/1028315316662978

Pham, H.-H., Lai, S. L., \& Vuong, Q.-H. (2019). The role of subjective task value in forming satisfaction and loyalty among Vietnamese international students: A structural equation model. The Asia-Pacific Education Researcher, 28(5), 399-409. https:// doi.org/10.1007/s40299-019-00439-3

Rolfsman, E. (2020). Swedish students in the process of transition to upper secondary education: Factors of importance for educational choice and for their future. 
Education Inquiry, 11(4), 331-359. https:/ / doi.org/10.1080/20004508.2020.1746480

Savolainen, H., Ahonen, T., Aro, M., Tolvanen, A., \& Holopainen, L. (2008). Reading comprehension, word reading and spelling as predictors of school achievement and choice of secondary education. Learning and Instruction, 18(2), 201-210. https://doi.org/10.1016/j.learninstruc.2007.09.017

Sharif, K., \& Kassim, N. M. (2012). Non-academic service quality: Comparative analysis of students and faculty as users. Journal of Marketing for Higher Education, 22(1), 3554. https://doi.org/10.1080/08841241.2012.705793

Sultan, P., \& Yin Wong, H. (2013). Antecedents and consequences of service quality in a higher education context. Quality Assurance in Education, 21(1), 70-95. https://doi.org/10.1108/09684881311293070

Teeroovengadum, V., Kamalanabhan, T. J., \& Seebaluck, A. K. (2016). Measuring service quality in higher education: Development of a hierarchical model (HESQUAL). Quality Assurance in Education, 24(2), 244-258. https://doi.org/10.1108/QAE-062014-0028

Teeroovengadum, V., Nunkoo, R., Gronroos, C., Kamalanabhan, T. J., \& Seebaluck, A. K. (2019). Higher education service quality, student satisfaction and loyalty: Validating the HESQUAL scale and testing an improved structural model. Quality Assurance in Education, 27(4), 427-445. https://doi.org/10.1108/QAE-01-20190003

Vuong, Q.-H. (2020). Reform retractions to make them more transparent. Nature, 582(7811), 149-149. https://doi.org/10.1038/d41586-020-01694-x

Wiers-Jenssen, J., Stensaker, B., \& Gr Øgaard, J. B. (2002). Student satisfaction: Towards an empirical deconstruction of the concept. Quality in Higher Education, 8(2), 183-195. https:// doi.org/10.1080/1353832022000004377 